\title{
Pengembangan Penuntun Praktikum Berbasis Inkuiri Terbimbing Materi Interaksi Makhluk Hidup pada Siswa MTs Darul Amin Palangka Raya
}

\author{
Lidia Aprilia ${ }^{1,}$,, Nanik Lestariningsih ${ }^{2}$, Ayatusa'adah $^{3}$ \\ ${ }^{1,2,3}$ IAIN Palangka Raya, Jln. G.Obos Komplek Islamic Center, Palangka Raya \\ *Alamat email koresponden: aprilialidia8@gmail.com
}

\begin{abstract}
The aim of this research was to develop a practical guide based on guided inquiry on the interaction material of living things. This type of research was Research and Development with the ADDIE development model (Analyze, Design, Development, Implement and Evaluation). Practicum guides were validated by 2 media experts and 2 material experts. The research was carried out until a small scale test with the research subjects were 5 grade students of MTs Darul Amin Palangkaraya. The results of the study were a practical guide with 3 topics whose activities were designed according to the guided inquiry learning model. The practicum guide developed was declared feasible by material and media experts with a very valid category. Based on small-scale trials, the practicality value was produced with a percentage of $83.00 \%$ which was categorized as very good. These results showed that the practicum guide was declared valid and practical after a small-scale trial was carried out. The practicum guide still needs to be refined for further trials on a large scale
\end{abstract}

Keywords: development, guided inquiry, practicum guide.

\section{PENDAHULUAN}

Permendiknas No. 22 Tahun 2006 tentang Standar Kompetensi dan Kompetensi Dasar Kurikulum Tingkat Satuan Pendidikan menyebutkan IPA berkaitan dengan cara memahami alam secara sistematis, sehingga IPA bukan hanya sebatas penguasaan kumpulan pengetahuan (produk ilmu) yang berupa fakta-fakta, konsep-konsep, atau prinsip-prinsip saja, tetapi lebih sebagai proses penemuan (BNSP, 2006). Berdasarkan pernyataan tersebut maka proses pembelajaran IPA sebaiknya menekankan pada pemberian pengalaman langsung salah satunya melalui kegiatan praktikum.

Kegiatan praktikum dapat berjalan teratur dengan adanya penuntun praktikum. Penuntun praktikum merupakan bahan ajar tertulis yang membantu guru pada proses pembelajaran. Penggunaan penuntun praktikum penting dalam kegiatan praktikum karena dalam pelaksanaannya kegiatan praktikum perlu adanya persiapan, selain 112 pengetahuan dari materi yang diperoleh, peserta didik juga memerlukan pedoman untuk menunjang terlaksananya praktikum. Pedoman tersebut berupa penuntun praktikum.

Budiarti (2013: 124) menyatakan penuntun praktikum adalah pedoman pelaksanaan praktikum yang berisi tata cara persiapan, pelaksanaan, analisis data dan pelaporan. Penuntun praktikum merupakan rujukan peserta didik dalam melaksanakan praktikum. Ketersediaan penuntun peserta didik dapat memiliki kesiapan sebelum melaksanakan kegiatan praktikum dengan membaca buku tersebut terlebih dahulu.

Penuntun praktikum didesain sesuai model inkuiri terbimbing. Model inkuiri terbimbing merupakan salah satu model pembelajaran yang membiasakan peserta didik secara aktif. Menurut Sanjaya (2010), inkuiri terbimbing memiliki keunggulan yakni dapat memberikan ruang kepada 
peserta didik untuk belajar sesuai dengan gaya mereka dan merupakan strategi yang dianggap sesuai dengan perkembangan psikologi belajar modern yang menganggap belajar adalah proses perubahan tingkah laku berkat adanya pengalaman.

Berdasarkan hasil wawancara analisis kebutuhan yang didapatkan dari salah seorang guru IPA kelas VII MTs Darul Amin Palangka Raya diketahui beberapa aspek yakni mengenai potensi akademik peserta didik, karakter peserta didik dalam pembelajaran IPA, sarana prasarana sekolah, media metode serta model yang digunakan guru dalam pembelajaran, pelaksanaan kegiatan praktikum serta kebutuhan guru dalam pembelajaran IPA. Potensi akademik peserta didik kelas VII MTs Darul Amin Palangka Raya dapat dilihat dari hasil belajar peserta didik untuk materi Interaksi Makhluk Hidup dengan Lingkungan. Hasil belajar peserta didik dinilai kurang karena 86\% peserta didik belum mencapai nilai ketuntasan minimal yang ditetapkan oleh guru. Hasil belajar peserta didik pada materi ini banyak yang tidak memenuhi kriteria ketuntasan belajar (KKB) yang ditetapkan oleh sekolah yaitu 70 .

Berdasarkan hasil wawancara diketahui bahwa ketidaktuntasan hasil belajar peserta didik tersebut disebabkan karena karakter peserta didik yang mudah merasa bosan dan kurangnya motivasi serta minat peserta didik dalam pembelajaran IPA sehingga mereka cenderung kurang memahami materi yang diajarkan khususnya pada materi Interaksi Makhluk Hidup dan Lingkungan. Namun, peserta didik akan merasa antusias dan aktif ketika melakukan kegiatan praktikum khususnya praktikum materi Interaksi Makhluk Hidup dengan Lingkungan. Guru menerangkan bahwa penerapan praktikum materi interaksi makhluk hidup dengan lingkungan ini hanya dilakukan di luar sekolah dengan melihat lingkungan di sekitar sekolah. Penerapan model inkuiri terbimbing juga belum pernah digunakan oleh guru tersebut.

Berdasarkan penuturan salah satu peserta didik kelas VII mengenai proses pembelajaran IPA yakni pembelajaran IPA Terpadu mata pelajaran Biologi di sekolah MTs Darul Amin Palangka Raya masih menggunakan metode konvensional, proses belajar mengajar masih berpusat pada guru (teacher-centered). Guru mendominasi pembelajaran sehingga peserta didik pasif dalam pembelajaran. Guru lebih menekankan pada penguasaan konsep dimana guru kebanyakan hanya memberikan serangkaian latihan dan soal walupun terkadang pada proses pembelajaran guru juga melakukan kegiatan praktikum terhadap konsep yang diajarkan namun hal itu jarang dilakukan selain itu kegiatan praktikum tersebut hanya dilakukan secara sederhana.

Sulitnya belajar IPA karena kurangnya pemahaman mengenai konsep yang diajarkan karena kurangnya penjelasan dari guru, lebih banyak tugas merangkum dan tidak adanya praktek langsung untuk materi interaksi makhluk hidup dan lingkungan. Kegiatan praktikum perlu dilakukan pada proses pembelajaran IPA. Pada penerapannnya perlu penuntun praktikum agar jalannya kegiatan terorganisir dengan baik. Guru memiliki penuntun praktikum materi ekosistem tapi tidak pernah digunakan sama sekali dan bersifat sederhana. Ketika guru ingin melakukan kegiatan praktikum, guru hanya mengacu pada penuntun praktikum yang ada di buku ajar peserta didik. Oleh karena itu berdasarkan hasil wawancara analisis kebutuhan guru menginginkan penuntun 
praktikum khusus materi Interaksi Makhluk Hidup dengan Lingkungan. Penuntun ini dikembangkan dari bahan ajar peserta didik yaitu buku IPA terpadu dengan desain gambar-gambar yang relevan serta pengetahuan tambahan mengenai materi Interaksi Makhluk Hidup dengan Lingkungan agar dapat memberikan wawasan ilmu pada peserta didik mengenai materi ini.

Uraian tersebut mendasari perlunya sebuah penelitian Pengembangan Penuntun Praktikum Materi Interaksi Makhluk Hidup dengan Lingkungan Berbasis Inkuiri Terbimbing terhadap Keterampilan Proses Sains Kelas VII Mts Darul Amin Palangkaraya. Penuntun praktikum yang dikembangkan diharapkan bisa menjadi pendamping pembelajaran utama yang ada di kelas dengan melakukan praktikum. Dengan adanya penuntun praktikum ini diharapkan guru IPA kelas VII tidak lagi terkendala dalam mengkondisikan peserta didik pada saat pelaksanaan praktikum.

\section{METODE}

Metode dalam penelitian ini adalah Research and Development dengan model pengembangan ADDIE. Adapun tahapan dalam penelitian ini yaitu tahap analisis, desain, pengembangan, implementasi dan evaluasi. (Sugiono, 2011). Prosedur dalam penelitian ini terdiri atas 3 tahap yaitu :

1. Tahap Analisis

Tahap analisis yang dilakukakan adalah analisis terhadap permasalahan di sekolah baik dari guru maupun peserta didik.

2. Tahap Desain

Hal-hal yang akan dilakukan peneliti dalam tahap desain yaitu membuat peta kebutuhan penuntun praktikum, menentukan isi penuntun praktikum, menyusun instrumen penelitian, dan validasi instrumen penelitian oleh dosen ahli. Pada tahap ini penuntun praktikum dirancang dengan model inkuiri terbimbing .

3. Tahap Pengembangan

Hal-hal yang akan dilakukan peneliti pada tahap pengembangan yaitu penulisan penuntun praktikum dan validasi penuntun praktikum oleh ahli materi dan ahli media. Penuntun praktikum yang dibuat dilengkapi dengan pengetahuan umum tentang lingkungan dengan tujuan menambah pengetahuan bagi peserta didik.

Validasi penuntun praktikum dilakukan oleh dua orang validator terhadap materi dan media. Validasi dilakukan untuk mengetahui kelayakan penuntun praktikum. Setelah dilakukan validasi penuntun praktikum tersebut dilakukan perbaikan sesuai penilaian, masukan dan saran validator. Jika sudah dinyatakan valid maka penuntun praktikum bisa diujicobakan.

Uji coba skala kecil dilakukan untuk melihat keterbacaan dan kepraktisan penuntun praktikum oleh peserta didik. Uji coba skala kecil dilakukan pada 5 orang peserta didik. Peserta didik terdiri atas 1 laki-laki dan 4 perempuan. Peserta didik yang mengkuti penelitian ini berasal dari 4 orang kelas VII $C$ dan 1 orang kelas VII B.

Pengumpulan data pada penelitian ini menggunakan angket validasi dan angket kepraktisan. Angket validasi terdiri dari angket validasi ahli materi dan angket validasi ahli media. Dalam penelitian ini melibatkan 2 orang ahli untuk memvalidasi. Angket kepraktisan 
digunakan saat uji coba kelompok kecil untuk mengetahui keterbacaan dan kperaktisan angket oleh peserta didik.

Data yang diperoleh akan dirataratakan pada setiap aspek kompenen penilaian. Untuk menetukan kevalidan dan kepraktisan penuntun praktikum dilihat dari kriteria validatas pada Tabel 1 dan kriteria kepraktisan pada Tabel 2.

Tabel 1. Kriteria Validitas

\begin{tabular}{ccc}
\hline No & Interval & Kriteria \\
\hline 1 & $81-100$ & Sangat Valid \\
2 & $61-80$ & Valid \\
3 & $41-60$ & Cukup Valid \\
4 & $21-40$ & Kurang Valid \\
5 & $0-20$ & Tidak Valid
\end{tabular}

Sumber: Ridwan (2013)

Tabel 2. Kriterai Kepraktisan

\begin{tabular}{ccc}
\hline No & Interval & Kriteria \\
\hline 1 & $81-100$ & Sangat Praktis \\
2 & $61-80$ & Praktis \\
3 & $41-60$ & Cukup Praktis \\
4 & $21-40$ & Kurang Praktis \\
5 & $0-20$ & Tidak Praktis \\
\hline
\end{tabular}

Sumber: Ridwan (2013)

\section{HASIL DAN PEMBAHASAN}

Pengembangan penuntun praktikum dilakukan melalui model pengembangan ADDIE yang dilakukan sesuai dengan kebutuhan penelitian. Penelitian hanya dilakukan sampai tahapan pengembangan.

Tahapan pertama yang dilakukan adalah Analisis kebutuhan. Berdasarkan hasil angket pada peseta didik diketahui bahwa peserta didik merasa tampilan dan isi penuntun praktikum kurang menarik. Peserta didik merasa perlu adanya penuntun praktikum khusus dengan tampilan yang menarik ditambah karakter animasi.

Hasil wawancara dengan guru menjelaskan penuntun praktikum diperlukan untuk menujang proses pembelajaran agar peserta didik terlibat aktif dalam proses pembelajaran. Trisnawati (2011: 122) menyatakan bahwa petunjuk praktikum diperlukan sebagai panduan praktikum supaya dapat berjalan dengan lancar. Peserta didik akan lebih teratur dalam melaksanakan kegiatan praktikum.

Berdasarkan hal tersebut maka perlu adanya pengembangan penuntun praktikum. Produk penuntun praktikum yang dikembangkan dalam penelitian ini memiliki beberapa rancangan yaitu bagian isi yang mengikuti langkah-langkah inkuiri terbimbing. Penuntun praktikum ini dibuat dengan mengikuti langkah inkuiri terbimbing karena menurut Wartono (1999) mengungkapkan dalam proses belajar mengajar dengan model pembelajaran inkuiri terbimbing, peserta didik dituntut untuk menemukan konsep melalui petunjukpetunjuk seperlunya dari seorang guru. Rustaman (2005) juga menyatakan bahwa pendekatan pembelajaran ini dapat melibatkan peserta didik secara aktif dalam kegiatan belajar. Pembelajaran dengan langkah inkuiri terbimbing dapat menekankan pada kreatifitas belajar peserta didik dalam mencari pemecahan masalah pada proses pembelajaran secara aktif dan mandiri mampu mendorong peserta didik dalam memecahkan masalah pada kegiatan praktikum. Metode pembelajaran ini juga dilaporkan efektif meningkatkan hasil belajar siswa SMP (Prasetyowati, 2020).

Hasil analisis kebutuhan menjadi dasar dalam penyusunan desain penuntun peraktikum. Struktur penuntun praktikum yang dikembangkan terdiri atas sampul depan dan belakang, edisi, sambutan, kata pengantar, daftar isi, karakteristik penuntun praktikum, petunjuk umum, format penulisan laporan praktikum, kompetensi dasar dan indikator, topik praktikum, glosarium dan daftar pustaka. Desain penuntun praktikum yang dikembangkan mengacu kepada susunan kegiatan praktikum yang disesuaikan dengan langkah-langkah inkuiri terbimbing. 
Pada tahap desain ini juga di buat beberapa unsur-unsur yang harus dimuat dalam penuntun praktikum yang meliputi penentuan struktur penuntun praktikum dan membuat instrumen penelitian yang divalidasi oleh ahli.

Tahap ketiga dalam proses pengembangan penuntun praktikum ini adalah tahap pengembangan. Pada tahap ini peneliti mengembangkan bahan ajar yang yang sudah ada di sekolah yakni berasal dari penuntun praktikum sederhana yang tercantum pada buku peserta didik. Penuntun praktikum dikembangkan dalam bentuk buku cetak penuntun praktikum berbasis inkuiri terbimbing MTs kelas VII menggunakan aplikasi Ms. Office dan Adobe Ilustrator.

Pada tahap ini dilakukan penilaian terhadap penuntun praktikum untuk mengetahui validitas dan kepraktisan penuntun praktikum. Validitas merupakan keadaan dimana suatu instrumen dapat mengukur suatu keadaan yang harus diukur secara tepat (Rahayu dan Festiyed, 2018). Uji validitas adalah suatu langkah pengujian yang dilakukan terhadap isi (content) dari suatu instrumen, dengan tujuan untuk mengukur ketepatan instrumen. Sedangkan kepraktisan mengacu pada tingkat bahwa pengguna (atau para pakar lainnya) mempertimbangkan intervensi dapat digunakan dan disukai dalam kondisi normal. Bahan ajar harus memenuhi aspek kepraktisan yaitu pemahaman dan keterlaksanaan bahan ajar tersebut. Kepraktisan menunjukkan tingkat kemudahan penggunaan, pelaksanaan serta pengelolaan dan penafsiran hasilnya (Mudjijo, 1995).

Validitas dan kepraktisan dari penelitian ini menunjukkan hasil valid dan menghasilkan respon sangat praktis. Sebagaimana akan dijabarkan di bawah ini.

\section{Validasi Ahli Materi}

Validasi ahli materi dilakukan oleh dua dosen IAIN Palangka Raya. Proses validasi tersebut menghasilkan beberapa perbaikan yakni:

1.Pada bagian prosedur kerja lebih diperjelas misalnya dengan menambahkan perintah menggambar hasil pengamatan untuk melatih keterampilan peserta didik.

2.Pada bagian evaluasi topik 1 ditambahkan satu pertanyaan lagi mengenai faktor-faktor yang berpengaruh terhadap pertumbuhan kacang hijau

3.Setiap topik bisa ditambahkan integrasi ayat Al-Qur'an yang berhubungan dengan interaksi makhluk hidup dengan lingkungan. Hal ini bertujuan agar peserta didik tidak hanya memahami secara sains tapi pemahaman religius yang juga lebih penting untuk menambah kecintaan kepada sang pencipta Allah SWT.

Adapun hasil analisis validasi ahli materi terhadap penuntun praktikum dapat dilihat pada Tabel 3. Berdasarkan hasil validasi diketahui, penuntun praktikum dari segi materi dikategorikan sudah valid. Berdasarkan penilaian ahli diketahui kelayakan penuntun praktikum materi interaksi makhluk hidup dengan lingkungan berbasis inkuiri terbimbing terhadap keterampilan proses sains kelas VII MTs Darul Amin Palangka Raya. Berdasarkan penilaian oleh ahli materi didapatkan presentase $78,90 \%$ dan $87,50 \%$ dengan kriteria valid dan sangat valid. Hasil validasi tersebut menunjukkan dari aspek kelayakan isi, penyajian maupun bahasa sudah valid untuk digunakan dalam kegiatan pembelajaran khususnya pada praktikum. 
Tabel 3 Data Hasil Validasi Ahli Materi

\begin{tabular}{ccccc}
\hline \multirow{2}{*}{ Aspek yang dinilai } & \multicolumn{4}{c}{ Hasil Perolehan Skor } \\
\cline { 2 - 5 } & Validator I & Validator II & Rata-rata & Persentase \\
\hline Isi & 39 & 41 & 40 & $83,33 \%$ \\
Penyajian & 31 & 35 & 33 & $83 \%$ \\
Bahasa & 31 & 36 & 33,5 & $84 \%$ \\
Jumlah Skor (\%) & $78,90 \%$ & $87,50 \%$ & $83,20 \%$ & $83,19 \%$ \\
\hline Kriteria & Valid & Sangat Valid & Sangat Valid & Sangat Valid \\
\hline
\end{tabular}

Tabel 4 Data Hasil Validasi Ahli Media

\begin{tabular}{ccccc}
\hline \multirow{2}{*}{ Indikator Penilaian } & \multicolumn{4}{c}{ Hasil Perolehan Skor } \\
& Validator I & Validator II & Rata-rata & Persentase \\
\hline Ukuran Penuntun Praktikum & 6 & 6 & 6 & $81 \%$ \\
Desain Sampul Penuntun & 25 & 22 & 23,5 & $74 \%$ \\
Praktikum & 56 & 50 & 53 & $78 \%$ \\
Desain Penuntun Praktikum & $80,55 \%$ & $72,22 \%$ & $76,38 \%$ & $78 \%$ \\
Jumlah Skor (\%) & Sangat Valid & Valid & Valid & Valid \\
\hline Kriteria & & & &
\end{tabular}

Tabel 5. Data Hasil Validasi Peserta Didik

\begin{tabular}{ccccc}
\hline No & Responden & Jumlah & Presentase & Kriteria \\
\hline 1 & R1 & 77 & $77,00 \%$ & Valid \\
2 & R2 & 98 & $98,00 \%$ & Sangat Valid \\
3 & R3 & 78 & $78,00 \%$ & Valid \\
4 & R4 & 77 & $77,00 \%$ & Valid \\
5 & R5 & 76 & $76 \%$ & Valid \\
\hline & Rata-rata & 81,2 & $81,20 \%$ & Sangat Valid \\
\hline
\end{tabular}

Tabel 6 Hasil Respon Peserta Didik Terhadap Produk

\begin{tabular}{ccccc}
\hline No & Responden & Jumlah & Presentase & Kriteria \\
\hline 1 & R1 & 50 & $83,33 \%$ & Sangat praktis \\
2 & R2 & 52 & $86,66 \%$ & Sangat praktis \\
3 & R3 & 49 & $81,66 \%$ & Sangat praktis \\
4 & R4 & 44 & $73,33 \%$ & Praktis \\
5 & R5 & 54 & $90 \%$ & Sangat praktis \\
\hline & Rata-rata & 49,8 & $83,00 \%$ & Sangat praktis \\
\hline
\end{tabular}

\section{Validasi Ahli Media}

Validasi ahli media dilakukan oleh dua dosen IAIN Palangka Raya. Proses validasi tersebut menghasilkan beberapa perbaikan yakni:

1. Pada bagian gambar sampul disesuaikan kembali dengan materi interaksi makhluk hidup dengan lingkungan
2. Warna logo IAIN Palangka Raya di bagian tengah diberi warna putih

3. Tata letak gambar pada bagian sampul dan isi lebih disesuaikan lagi untuk memberikan kemudahan kepada peserta didik dalam memahami isi dari penuntun praktikum.

Adapun hasil analisis validasi ahli media terhadap penuntun praktikum dapat 
dilihat pada Tabel 4. Kelayakan penuntun praktikum juga dapat dilihat dari kevalidan penuntun praktikum sebagai media pembelajaran sehingga perlu adanya uji validasi oleh pakar/ahli media. Berdasarkan penilaian oleh ahli media didapatkan presentase $80,55 \%$ dan $72,22 \%$ dengan kriteria sangat valid dan valid. Hasil validasi tersebut menunjukkan dari ukuran penuntun praktikum, desain sampul

penuntun praktikum (cover), dan desain isi penuntun praktikum sudah valid untuk digunakan dalam kegiatan pembelajaran khususnya pada kegiatan praktikum.

\section{Validasi Peserta Didik}

Pada penelitian ini data validasi peserta didik bisa didapatkan setelah melakukan uji coba produk skala kecil. Validasi produk oleh peserta didik dilakukan setelah peserta didik menggunakan penuntun praktikum selama proses pembelajaran. Validasi dilakukan untuk mengetahui kevalidan dari penuntun praktikum apakah layak atau tidak untuk digunakan pada pembelajaran IPA. Validasi dilakukan pada 5 peserta didik dari kelas VIIC dan VIIB. Hasil penilaian peserta didik terhadap produk penuntun praktikum dapat dilihat pada Tabel 5.

Berdasarkan hasil validasi baik dari validator ahli maupun peserta didik diketahui bahwa penuntun praktikum yang dikembangkan sangat valid sehingga baik digunakan untuk membantu proses pembelajaran. Hasil validasi sejalan dengan penelitian Syamsu (2015) yang mana berdasarkan rata-rata skor penilaian validator dihasilkan kategori sangat valid. Hal ini terjadi karena komponen-komponen yang ada telah terpenuhi berdasarkan penilaian validator.

\section{Respon Peserta Didik}

Pada penelitian ini data respon peserta didik juga bisa didapatkan setelah melakukan uji coba produk skala kecil. Pada proses ini, tingkat kepraktisan dapat dikur dengan memberikan angket respon kepada peserta didik untuk mengetahui respon peserta didik terhadap penuntun praktikum yang digunakan. Angket respon diberikan kepada peserta didik untuk mengetahui tingkat kemudahan penuntun praktikum yang dikembangkan. Berdasarkan angket respon didapatkan data kepraktisan yaitu beberapa komentar dan saran dari peserta didik. Data kepraktisan didapatkan dari 5 peserta didik yang telah menggunakan penuntun praktikum pada saat pembelajaran. Angket respon peserta didik diserahkan pada saat peserta didik telah selesai melakukan proses pembelajaran dengan metode praktikum dari topik 1-topik 3. Hasil perolehan nilai untuk angket respon peserta didik dapat dilihat pada Tabel 6 .

Hasil respon peserta didik menujukkan kategori sangat baik yang artinya penuntun praktikum memudahkan peserta didik dalam melakukan kegiatan praktikum. Hal ini sejalan dengan penelitian Nengsi (2016) yang mana pada hasil praktikalitasnya menunjukkan hasil sangat baik yang berarti penuntun praktikum berbasis inkuiri terbimbing dapat memudahkan dan membantu peserta didik dalam melaksanakan kegiatan praktikum. 


\section{KESIMPULAN DAN SARAN}

Penuntun praktikum materi interaksi makhluk hidup dengan lingkungan berbasis inkuiri terbimbing kelas VII MTs Darul Amin Palangka Raya dikembangkan dalam bentuk cetak dengan kertas HVS untuk bagian isi dan kertas sampul untuk bagian sampul. Penuntun praktikum disusun berdasarkan urutan sintaks atau langkahlangkah inkuiri terbimbing serta pada penuntun pratikum terdapat pengetahuan umum "Tahukah Kamu?" untuk menambah wawasan peserta didik terkait lingkungan.

Hasil validitas dari ahli materi dan ahli media menunjukkan penuntun praktikum sudah layak digunakan dengan kriteria sangat valid. Validitas penuntun praktikum dari hasil penilaian peserta didik menunjukkan kriteria sangat valid dengan presentase $81,20 \%$. Kemudian dari segi kepraktisan didapatkan dari respon peserta didik dan dihasilkan presentase sekitar $83,00 \%$ dengan kategori sangat praktis. Berdasarkan hasil validasi dan uji skala kecil penuntun praktikum layak dan praktis untuk digunakan

\section{UCAPAN TERIMAKASIH}

Terimakasih kepada semua pihak yang terlibat dalam penelitian dan penyusunan artikel ini. Kepala Sekolah dan guru yang telah memberikan izin pelaksanaan kegiatan penelitian di MTs Darul Amin Palangka Raya serta Temanteman yang terlibat dalam penelitian ini.

\section{DAFTAR PUSTAKA}

Anwar, K. (2016). Implementasi Model Pembelajaran Generatif Dalam Mata Pelajaran Perawatan Perbaikan Mekanik Otomotif (Ppmo) Teknologi Sepeda Motor. E-Jurnal Pendidikan Teknik Otomotif-S1, 13(1).

BSNP. 2006. Peraturan Menteri Pendidikan Nasional Republik Indonesia No. 22 Tahun 2006 Tentang
Standar Isi Untuk Satuan Pendidikan Dasar dan Menengah. Jakarta: Cipta Mini Jaya Abadi.

Budiarti, W. \& Anak Agung, O. (2014). Pengembangan Petunjuk praktikum Biologi Berbasis Pendekatan Ilmiah untuk Siswa SMA Kelas XI Semester Genap Tahun Pelajaran 2013/2014. Jurnal Bioedukasi, 6(2):123-130.

Mudjijo. 1995. Tes Hasil Belajar. Jakarta: Bumi Aksara

Natalina, M., Mahadi, I., \& Suzane, A. C. (2013). Penerapan Model Pembelajaran Inkuiri Terbimbing (Guided Inquiry) untuk Meningkatkan Sikap Ilmiah dan Hasil Belajar Biologi Siswa Kelas XI IPA-5 SMA Negeri 5 Pekan Baru Tahun Ajaran 2011/2012. Prosiding Semirata FMIPA Universitas Lampung.

Nengsi, S. (2016). Pengembangan Penuntun Praktikum Biologi Umum Berbasis Inkuiri Terbimbing Mahasiswa Biologi STKIP Payakumbuh. Jurnal IPTEKS Terapan, 10(1), 47-55.

Prasetyowati, T. (2020). Peningkatan Aktivitas dan Hasil Belajar Materi Sistem Ekskresi Melalui Inkuiri Terbimbing Pada Siswa SMP Negeri 1 Kemalang. Journal of Biology Learning, 2(2), 67-77.

Rahayu, C., \& Festiyed, F. (2018). Validitas perangkat pembelajaran fisika SMA berbasis model pembelajaran generatif dengan pendekatan openended problem untuk menstimulus keterampilan berpikir kritis peserta didik. Jurnal Pendidikan Fisika, 7(1), 1-6.

Ridwan. 2013. Cara Mudah Belajar SPSS 17 dan Aplikasi Statistik Penelitian. Bandung: Alfabeta.

Rizal, M. (2014). Pengaruh Pembelajaran Inkuiri Terbimbing Dengan Multi Representasi Terhadap Keterampilan Proses Sains Dan Penguasaan Konsep IPA Siswa SMP. Jurnal Pendidikan Sains, 2(3), 159-165.

Rustaman Nuryani Y, dkk. 2005. Strategi Belajar Mengajar Biologi. Malang: IKIF Malang.

Sanjaya, W. 2008. Strategi Pembelajaran Berorientasi Standar Proses Pendidikan. Jakarta: Kencana Prenada Media Group.

Sagala Syaiful. 2010. Konsep dan Makna Pembelajaran. Bandung: Alfabeta.

Sugiono. 2011. Metode Penelitian \& Pengembangan (Research and Development) Bandung: Alfabeta.

Sukoco Teo, Rumiyati, Sururi Adip Ma'rifu. 2016. Ilmu Pengetahuan Alam. Klaten: Intan Pariwara.

Syamsu, F. D. (2018). Pengembangan Penuntun Praktikum IPA Berbasis Inkuiri Terbimbing untuk Peserta didik SMP Peserta didik Kelas VII Semester Genap. Bionatural: Jurnal Ilmiah Pendidikan Biologi, 4(2).

Trisnawati, E. 2011. Pengembangan Petunjuk Praktikum Biologi Materi Struktur Sel dan Jaringan Berbasis Empat Pilar Pendidikan. 
Skripsi. Semarang: Universitas Negeri Semarang.

Wulanningsih, S., Prayitno, B. A., \& Probosari, R. M.

(2012). Pengaruh Model Pembelajaran Inkuiri

Terbimbing Terhadap Keterampilan Proses Sains

Ditinjau Dari Kemampuan Akademik Peserta

Didik SMA Negeri 5 Surakarta. Jurnal

Pendidikan Biologi, 4(2), 33-43. 